\title{
Investigation of ginkgo biloba leave extracts as corrosion and Oil field microorganism inhibitors
}

\author{
Gang Chen ${ }^{1}$, Min Zhang ${ }^{1}$, Jingrui Zhao ${ }^{2}$, Rui Zhou', Zuchao Meng ${ }^{1}$ and Jie Zhang ${ }^{1 *}$
}

\begin{abstract}
Ginkgo biloba (Ginkgoaceae), originating from China, now distributes all over the world. Wide application of Ginkgo biloba extracts is determined by the main active substances, flavonoids and terpenoids, which indicates its extracts suitable to be used as an effective corrosion inhibitor. The extracts of Ginkgo biloba leave have been investigated on the corrosion inhibition of Q235A steel with weight loss and potentiodynamic polarisation techniques. The inhibition efficiency of the extracts varies with extract concentration. The extracts inhibit corrosion mainly by adsorption mechanism. Potentiodynamic polarisation studies show that extracts are mixed type inhibitors. The antibacterial activity of the extracts against oil field microorganism (SRB, IB and TGB) was also investigated.
\end{abstract}

Keywords: Ginkgo biloba, Extract, Inhibition efficiency, Oil field microorganism

\section{Background}

To prove the crude oil recovery, acidification of the low permeable reservoirs is one of the efficient operations, during which hydrochloric acidic fluid is pumped into wells to etch the fracture walls irregularly and create highly conductive channels [1]. While it is also a great challenge for the metal instruments involved in the acidification, and there is a need to improve the resistance properties of the steel against such corrosion in acidic media. Great attention has been paid to prolonging the lifetime, in which the use of corrosion inhibitors is considered as the most effective method against such acid attack [2,3]. Functional electronegative groups and $p$-electron in conjugated double or triple bonds, are the major adsorption centers. So the organic compounds, containing heteroatoms, such as sulfur, phosphorus, nitrogen and oxygen, together with aromatic rings, are efficient as corrosion inhibitors [4-7].

Although many compounds have been synthesized for the corrosion inhibition, there is a need to develop green and eco-friendly corrosion inhibitors with low cost. In fact, many plants' extracts have been screened as corrosion inhibiters for mild steel [8-10], and the tremendous plant resources in Qin-ling and Ba-shan Mountain of

\footnotetext{
* Correspondence: zhangjie@xsyu.edu.cn

${ }^{1}$ College of Chemistry and Chemical Engineering, Xi'an Shiyou University,

Xi'an Shaanxi 710065, People's Republic of China

Full list of author information is available at the end of the article
}

Shannxi Province provide the guarantee for the natural material exploration. Ginkgo biloba (Ginkgoaceae), originating from China, was first introduced to Europe in the 18th century, and now distributes all over the world. Wide application of Ginkgo biloba extracts is determined by the main active substances: flavonoids and terpenoids (Figure 1) and has shown antioxidant activity in preliminary DPPH assays[11-14], which indicates the Ginkgo biloba extracts suitable to be used as an effective corrosion inhibitor. The aim of this work is to investigate the inhibitory action of Ginkgo biloba extract for the corrosion of mild steel of oil field.

\section{Experimental}

\section{Materials and methods}

Ginkgo biloba leave were washed and dried under $60^{\circ} \mathrm{C}$ and was shattered into powder, and the powder was heated with water or alcohol for $4 \mathrm{~h}$. Then a yellow aqueous extract was filtered to yield dry extract after removal of the solvent. The extract yield from the water and alcohol were named as WE and AE, and extraction rate of water and alcohol is $29.8 \%$ and $18.7 \%$ respectively.

\section{Gravimetric measurements}

The corrosion tests were performed on Q235A with a composition (in wt.\%) C: 0.22, P: 0.045, Si: 0.35, S: 0.05, $\mathrm{Mn}: 1.40$, and Fe balance. The electrolyte solution 


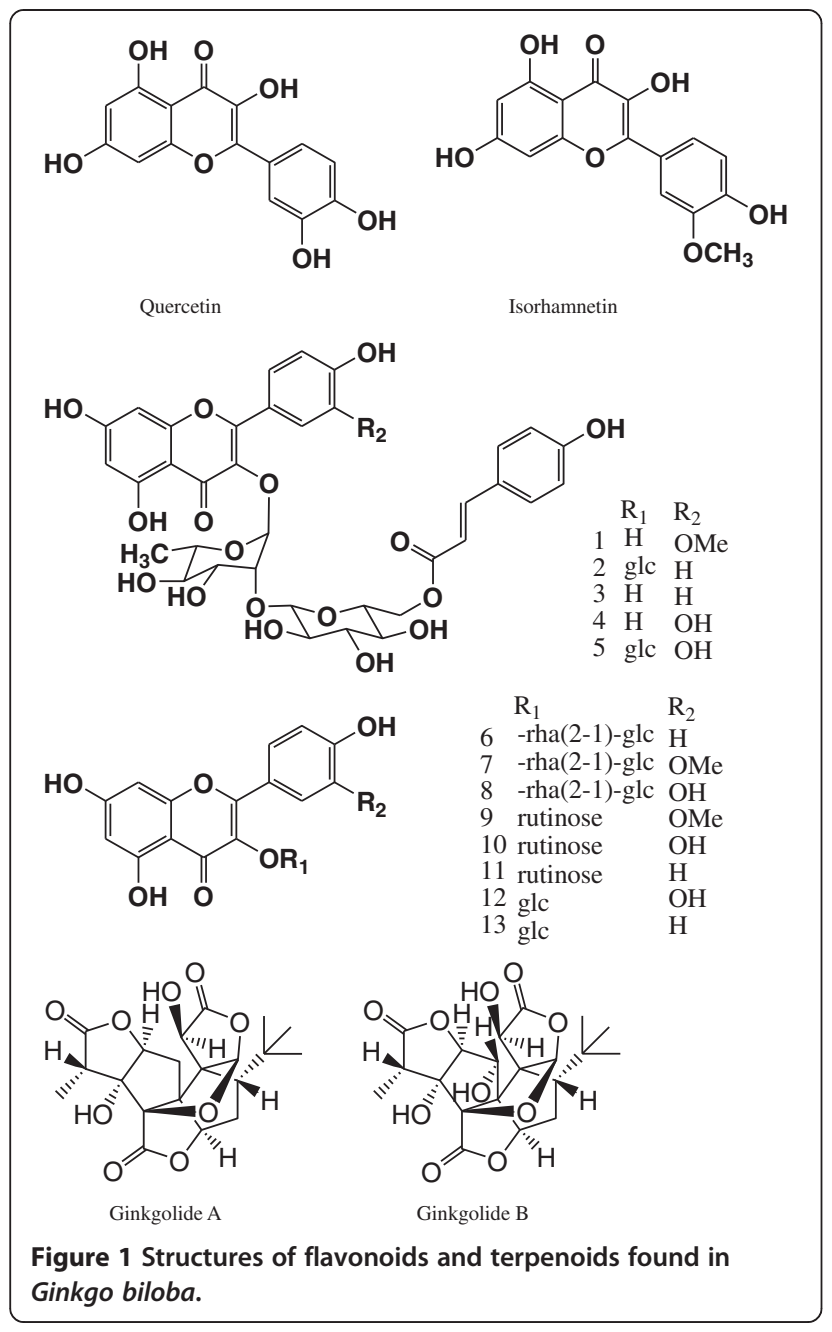

was $1 \mathrm{M} \mathrm{HCl}$, prepared from analytical grade $38 \% \mathrm{HCl}$ and distilled water. The concentrations of pomegranate husk extract were employed as $10 \mathrm{mg} / \mathrm{L}, 100 \mathrm{mg} / \mathrm{L}$ and $1000 \mathrm{mg} / \mathrm{L}$. All tests have been performed in deaerated solutions and at $60 \pm 0.5^{\circ} \mathrm{C}$. The gravimetric tests were carried out according to the People's Republic of China Standard of Petroleum and Natural Gas Industry (Evaluation method for behavior of corrosion inhibitor for produced water of oilfield, SY/T5273-2000) with a few modifications. Each test was done with three specimens at the same time to give reproducible results.

\section{Electrochemical measurements}

The electrodes were mechanically abraded with a series of emery papers (800 and 1200 grad). Then it was rinsed in acetone and double distilled water before their immersion in experimental solution. Electrochemical measurements were conducted in a conventional three-electrode thermostated cell. The electrode was inserted in Teflon tube and isolated with polyester so that only its section $\left(0.5 \mathrm{~cm}^{2}\right)$ was allowed to contact the aggressive solutions.
A platinum disk as counter electrode and standard calomel electrode (SCE) as the reference electrode have been used in the electrochemical studies.

The potentiodynamic curves were recorded using a CS350 system connected to a personal computer. The working electrode was first immersed into the test solution for $60 \mathrm{~min}$ to establish a steady state open circuit potential. After measuring the open circuit, potential dynamic polarisation curves were obtained with a scan rate of $0.5 \mathrm{mV} / \mathrm{s}$. Corrosion rates (corrosion current densities) were obtained from the polarisation curves by linear extrapolation of the anodic and cathodic branches of the Tafel plots at points $100 \mathrm{mV}$ more positive and more negative than the corrosion potential (Ecorr).

CS350 electrochemical workstation hardware parameters:

Potentiostat potential control: $\pm 10 \mathrm{~V}$; Current Control Range: $\pm 2.0 \mathrm{~A}$; Potential control precision: $0.1 \% \times$ full scale reading $\pm 1 \mathrm{mV}$; Current control accuracy: $0.1 \% \times$ full scale reading; Potential resolution: $10 \mu \mathrm{V}$ (>100 Hz), $2 \mu \mathrm{V}(<10 \mathrm{~Hz})$; Current resolution: <10pA; Potential rise time: $<1 \mu \mathrm{S}(<10 \mathrm{~mA}),<10 \mu \mathrm{S}(<2 \mathrm{~A})$; Auxiliary 24-bit data acquisition-10 KHz, 20bit-1 KHz; Reference electrode input impedance: 1012 ohms || 20pF; Current range 2A- $00 \mathrm{nA}$, a total of 8 files; Tank pressure: $21 \mathrm{~V}$; CV and LSV scan rate: $0.01-20000 \mathrm{mV} / \mathrm{s}$; CA and CC pulse width: 0.0001-1000 s; Potential scan potential incremental: $0.1 \mathrm{mV}-1 \mathrm{~V} / \mathrm{mS}$; SWV frequency: 0.001-100 KHz; DPV and NPV pulse width: 0.0001$1000 \mathrm{~s}$; AD data acquisition: 16 bits- $1 \mathrm{MHz}, 24 \mathrm{bit}-100$ $\mathrm{Hz}$; Minimum potential increment CV: $0.075 \mathrm{mV}$.

\section{Microbiological monitoring}

Viable counts of SRB, TGB and FB were determined according to the Standard of Petroleum and Natural Gas Industry of People's Republic of China (Method of SY/T 5890-1993, The national method of the bactericidal agent's performance). The produced water containing the three kinds of bacteria was gathered from Zichang Oilfield Factory, Yanchang Oilfield.

\section{Findings}

\section{Inhibitor properties and mechanism}

Q235A (A3) steel is widely used in the gas and oil field, and it is easily eroded in the presence of high concentration of $\mathrm{HCl}$ under high temperature. The use of corrosion inhibitors, such as imidazoline, Mannich base, Schiff base and some other heterocyclic compounds, is considered as the most effective method for the protection against such acid attack, but the concentration and the cost is too high to be accepted.

Developing natural products as oilfield chemicals is a direct way to find green and eco-friendly materials with 


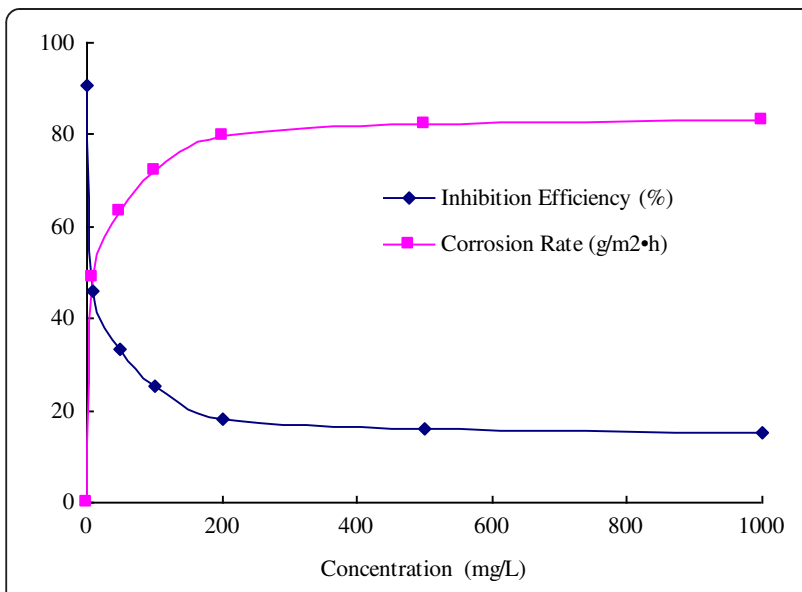

Figure 2 The inhibition efficiency and corrosion rate of WE.

low cost. Based on the various and large quantity of local resources of Qin-ling and Ba-shan Mountain, several plants have been investigated for the application in oilfield chemistry in our research work. The inhibition efficiency (IE) of extract of Ginkgo biloba leave was investigated with the concentration range from $10 \mathrm{mg} / \mathrm{L}$ to $1000 \mathrm{mg} / \mathrm{L}$ in $1 \mathrm{M} \mathrm{HCl}$, and the change of IE (\%) and corrosion rate $\left(\mathrm{g} / \mathrm{m}^{2} \cdot \mathrm{h}\right)$ with the inhibitor concentration were summarized in Figures 2 and 3. From the table, it was found that the extract can inhibit the corrosion with different efficiency under different concentrations, and the IE increases with the concentration. For WE, the IEs reach to $72.0 \%$ and $83.2 \%$ with the concentration of $100 \mathrm{mg} / \mathrm{L}$ and $1000 \mathrm{mg} / \mathrm{L}$ respectively, while the IEs of $\mathrm{AE}$ only reach to $66.7 \%$ and $77.7 \%$ respectively.

\section{Tafel polarisation measurements}

Both anodic and cathodic polarization curves for a carbon steel electrode in $1.0 \mathrm{M} \mathrm{HCl}$ at various concentrations of the WE and $\mathrm{AE}$ at $298 \mathrm{~K}$ are given in Figures 4

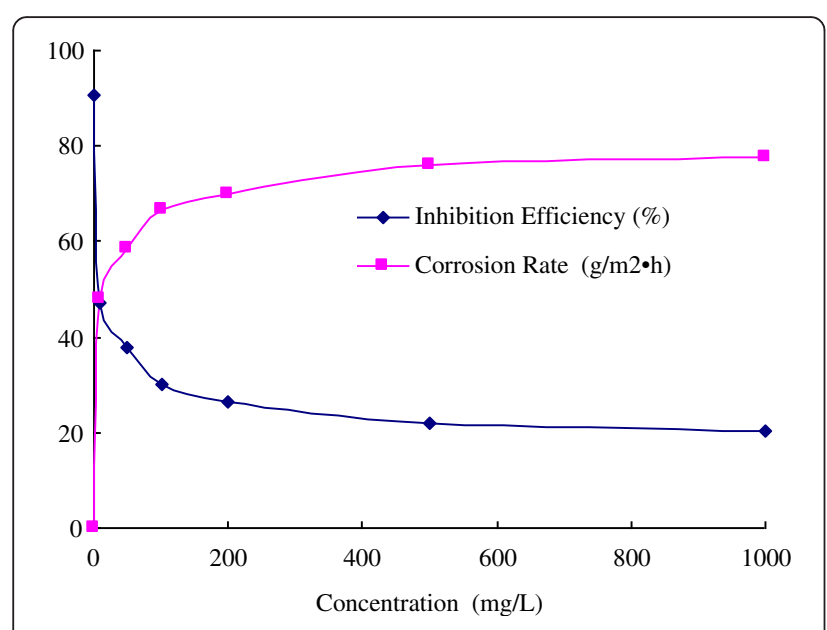

Figure 3 The inhibition efficiency and corrosion rate of AE.

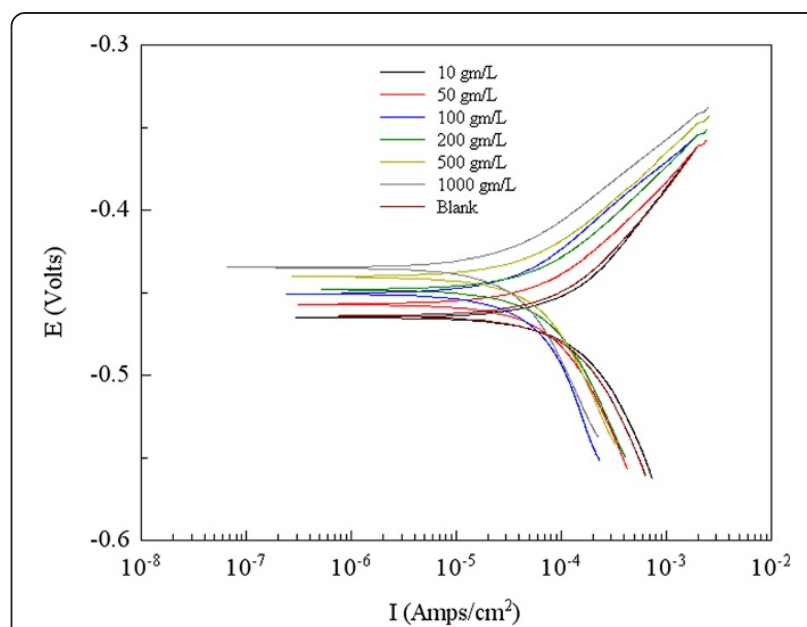

Figure 4 Typical polarization curves for corrosion of Q235A steel in $1 \mathrm{M} \mathrm{HCl}$ in the absence and presence of different concentrations of WE.

and 5. The electrochemical corrosion kinetic parameters, i.e., corrosion potential (Ecorr), cathodic and anodic Tafel slopes $(\beta a, \beta c)$ and corrosion current density icorr obtained by extrapolation of the Tafel lines are included in Table 1. The calculated inhibition efficiency, IE (\%) is also calculated from the following equation:

$$
E(\%)=\frac{I_{\text {corr }}-I_{\text {corr }(i)}}{I_{\text {corr }}} \times 100
$$

Where Icorr and Icorr(i) are corrosion current densities obtained in the absence and presence of inhibitors, respectively. It can be seen that the corrosion rate is

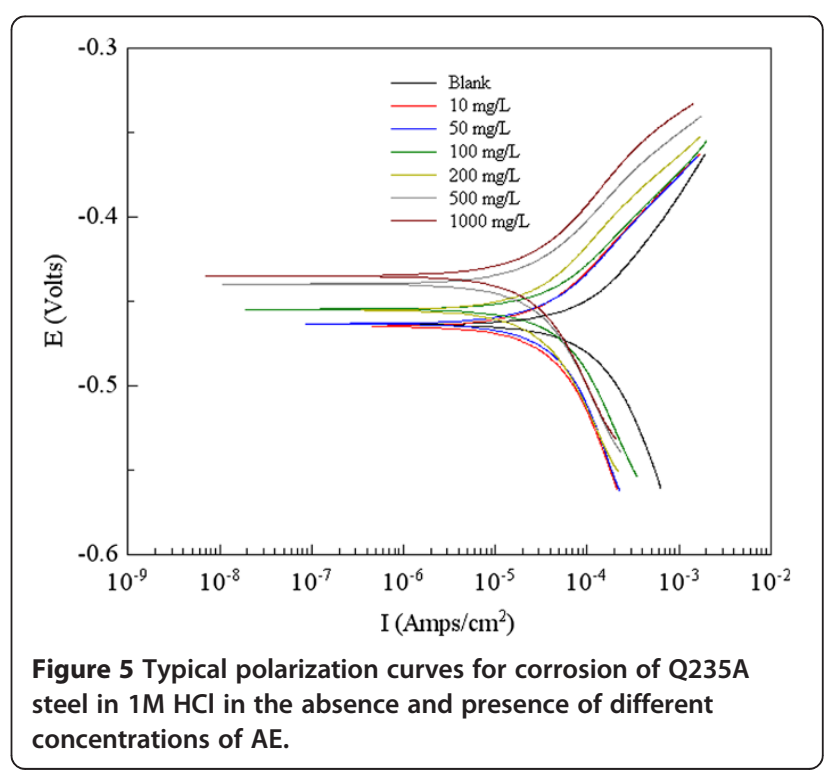


Table 1 Potentiodynamic polarization parameters for the corrosion of the Q230A steel in $1 \mathrm{M} \mathrm{HCl}$ in absence and presence of different concentrations of the extracts

\begin{tabular}{|c|c|c|c|c|c|c|c|}
\hline Extract & $\begin{array}{c}\text { Concentration } \\
(\mathrm{mg} / \mathrm{L})\end{array}$ & $\begin{array}{c}\text {-Ecorr } \\
(\mathrm{mV})\end{array}$ & $\begin{array}{c}\text { Icorr } \\
\left(\mu \mathrm{A} / \mathrm{cm}^{2}\right)\end{array}$ & $\begin{array}{c}\beta a \\
(\mathrm{mV} / \mathrm{dec})\end{array}$ & $\begin{array}{c}\beta c \\
(\mathrm{mV} / \mathrm{dec})\end{array}$ & $\begin{array}{c}\text { Corrosion rate } \\
(\mathrm{mm} / \mathrm{a})\end{array}$ & $\begin{array}{c}\text { IE } \\
\text { (\%) }\end{array}$ \\
\hline-- & -- & 0.46083 & 151.440 & 90.43 & 155.08 & 1.7753 & -- \\
\hline WE & 10 & 0.47503 & 131.180 & 86.83 & 160.49 & 1.5430 & 13.1 \\
\hline WE & 50 & 0.45705 & 96.410 & 72.35 & 151.56 & 1.1340 & 36.1 \\
\hline WE & 100 & 0.45056 & 57.454 & 65.77 & 161.94 & 0.6758 & 61.9 \\
\hline WE & 200 & 0.4455 & 55.195 & 59.85 & 143.79 & 0.6492 & 63.4 \\
\hline WE & 500 & 0.43980 & 34.272 & 55.18 & 134.99 & 0.4031 & 77.3 \\
\hline WE & 1,000 & 0.42657 & 33.219 & 52.64 & 128.09 & 0.3907 & 78.0 \\
\hline $\mathrm{AE}$ & 10 & 0.45347 & 111.570 & 77.58 & 152.17 & 1.3123 & 26.1 \\
\hline $\mathrm{AE}$ & 50 & 0.45128 & 85.704 & 67.94 & 129.73 & 1.0081 & 43.2 \\
\hline $\mathrm{AE}$ & 100 & 0.45489 & 54.511 & 65.70 & 121.36 & 0.6412 & 63.9 \\
\hline $\mathrm{AE}$ & 200 & 0.45549 & 31.770 & 64.64 & 113.19 & 0.3737 & 78.9 \\
\hline $\mathrm{AE}$ & 500 & 0.43987 & 29.917 & 62.11 & 112.71 & 0.3525 & 80.1 \\
\hline$A E$ & 1,000 & 0.42490 & 29.194 & 68.59 & 116.21 & 0.3434 & 80.7 \\
\hline
\end{tabular}

decreased and inhibition efficiency IE (\%) is increased by increasing inhibitor concentration [15]. The extract causes changes in the anodic, cathodic Tafel slopes and the Ecorr values in the presence of different concentrations, suggesting that these compounds behave as mixed-type (anodic/cathodic) inhibitors [16-18]. Increasing inhibition efficiencies with increasing concentrations of the extract shows that the inhibition actions are due to its adsorption on the steel surface $[19,20]$. The difference in inhibition efficiency between WE and AE may be due to the effect of the high water-soluble part, which includes the glycoside and some polysaccharide. The inhibition efficiencies obtained from potentiodynamic polarization were different from those calculated from weight-loss measurements, which may be attributable to the fact that the weight-loss method gives average corrosion rate, whereas electrochemical method gives instantaneous corrosion rates. These variations may also arise because of the difference in the time required to form an adsorbed layer of inhibitors on metal surface that can inhibit corrosion [21,22].

\section{Mechanism of corrosion inhibition}

It is well recognized that organic inhibitor molecules set up their inhibition action via the adsorption onto the metal/solution interface. The adsorption process is affected by the chemical structures of the inhibitors, the nature and charged surface of the metal and the distribution of charge over the whole inhibitor molecule. The presence of $\mathrm{N}, \mathrm{O}, \mathrm{S}$ atoms and conjugated double bonds in the organic structures makes the formation of $p-d$ bonds resulting from overlap of $p$-electrons to the $3 d$ vacant orbital of iron atoms, which enhances the adsorption of the compounds on the metal surface [23-25]. In general, organic inhibitor molecules may be adsorbed on the metal surface in one or more of the following ways [26,27]:
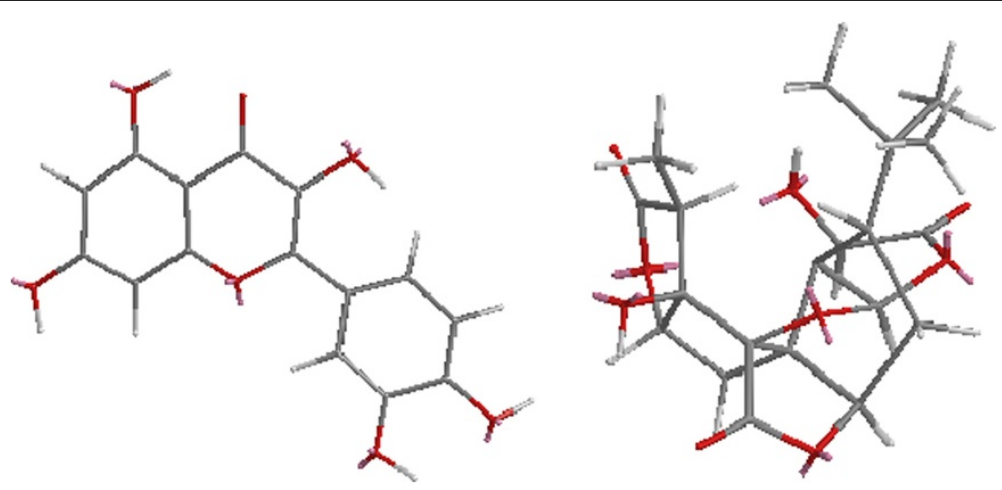

Figure 6 The steady conformation of Quercetin and Ginkgolide A. 


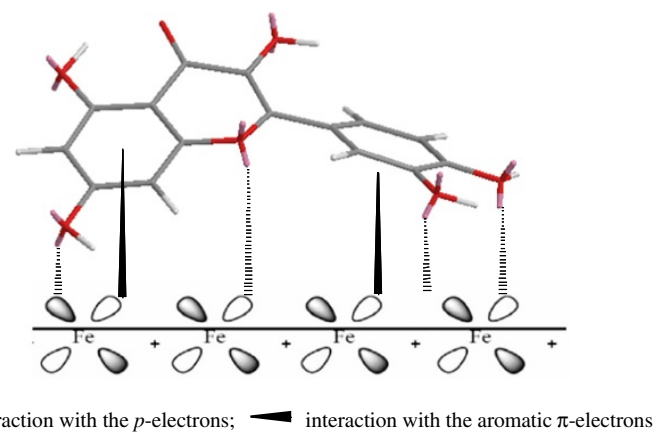

Figure 7 The absorption of Quercetin on the steel surface by coordination.

(a) electrostatic interaction between the charged molecules and the charged metal;

(b) interaction of unshared electron pairs in the molecule with the metal;

(c) interaction of p-electrons with the metal;

(d) a combination of types $(\mathrm{a}-\mathrm{c})$.

But owing to the complex nature of adsorption and inhibition of a given inhibitor, it is impossible for single adsorption mode between inhibitor and metal surface. The structures of phenols and terpenoids in Ginkgo biloba leave were shown in Figure 1, and the steady conformation of Quercetin and Ginkgolide A were shown in Figure 6, which were simulate by a minimize energy of MM2 in Chem 3D, and the p-electrons of the hydroxyl groups and ether groups were colored in pink.

The inhibition efficiency afforded by Quercetin may be attributed to the presence of electron rich phenol groups and aromatic rings, while Ginkgolide A may be attributed to the presence of electron rich $\mathrm{O}$. The possible reaction centers are unshared electron pair of heteroatoms and/or p-electrons of aromatic ring. Generally, Quercetin can absorb on the mild steel surface on the basis of donor-acceptor interactions between $p$-electrons of the $\mathrm{O}$ and aromatic ring and vacant $d$ orbitals of surface iron. The schematic illustration of different modes of adsorption on metal is shown in Figure 7. Besides, the flavonoids are high reductive and can be oxidized to benzoquinone by the $\mathrm{O}_{2}$ resolved in the solution, which can inhibit the oxygen-adsorption corrosion (as shown in Figure 8) $[28,29]$.

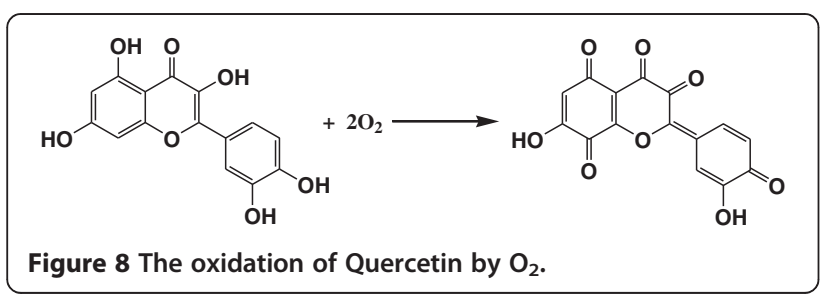

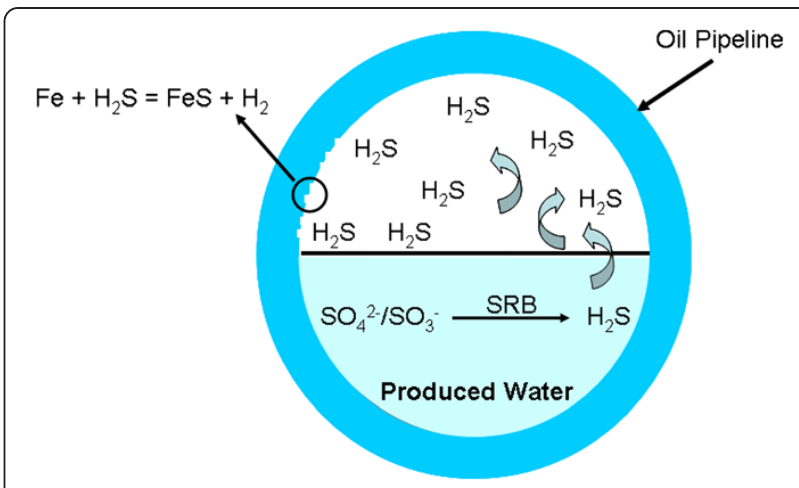

Figure 9 Mechanism of the microbial corrosion of oil pipelines.

Antibacterial activity against oil field microorganism

Produced water is a consequence of oil field exploitation by waterflood or steam injection or having an aquifer linking to the reservoir. The most usual disposal way for the high-volumed produced water is to re-inject it to the well after treatment, which will meet some requirements imposed by environmental and exploitation regulations [30], among which microbiologically influenced corrosion (MIC) is an example. MIC, mainly caused by the growth of such oil field microorganism as sulfate reducing bacteria (SRB), iron bacteria (IB) and total general bacteria (TGB) in oil pipelines, is considered as a major problem for water treatment in the oil field [31]. MIC can result in different types of attack, such as pitting, crevices, dealloying and erosion in pipelines (as shown in Figure 9) [32]. Even more serious, the interaction of IB, SRB and TGB can accelerate the corrosion rate, in other word, the corrosion in the mixture of IB, SRB and TGB was more serious than in a single microbial system. Based on this case, different treatment system to inhibit corrosion should be considered, among which using bactericide has received the greatest acceptance. Currently, oxidizer, aldehyde, quatemary ammonium salt and heterocycle compounds, such as $\mathrm{Cl}_{2}, \mathrm{ClO}_{2}$, formaldehyde, pentane-1,5-dial, trichloroisocyanuric acid (TCCA) and ect., have been used as bactericides [33,34], but the toxicity and oxidation tests have been conducted on a limited selection.

Table 2 The antifungal activity of Ginkgo biloba leave extract against oil field MIC

\begin{tabular}{ccccc}
\hline Extract & $\begin{array}{c}\text { Concentration } \\
\mathbf{m g} / \mathbf{L}\end{array}$ & \multicolumn{3}{c}{ Microbiotic concentration $\mathbf{m L}$} \\
\cline { 2 - 5 } & - & $\mathbf{S R B}$ & $\mathbf{I B}$ & TGB \\
\hline- & - & 110.0 & 110.0 & 110.0 \\
\hline WE & 500 & 2.0 & 1.3 & 20.0 \\
\cline { 2 - 5 } & 1,000 & 2.0 & 2.0 & 2.0 \\
\hline AE & 500 & 2.5 & 110.0 & 25.0 \\
\cline { 2 - 5 } & 1,000 & 2.5 & 6.0 & 2.5 \\
\hline
\end{tabular}


Since the structures of the main composition in Ginkgo biloba leave have been determined in Figure 1, and the flavonoids can combine with proteins and show some antibacterial activities [35], the extracts are anticipated to be bactericides for oil field bacteria. In the following work, the antifungal activity of these extracts against oil field microorganism was tested under the concentrations of $500 \mathrm{mg} / \mathrm{L}$ and $1,000 \mathrm{mg} / \mathrm{L}$, and the results are summarized in Table 2 . From the table, it is apparent that extracts are highly antifungal active against the three microorganisms under the concentration of $1,000 \mathrm{mg} / \mathrm{L}$. As the concentration of the extracts is reduced to $500 \mathrm{mg} / \mathrm{L}$, the inhibitions are still potent for most of the cases with slightly higher microbiotic concentrations. But the inhibitions of WE for TGB and AE for IB and TGB depressed obviously.

\section{Conclusions}

The water and alcohol extracts of Ginkgo biloba leave showed moderate to high effective inhibition in the range 10 to $1,000 \mathrm{mg} / \mathrm{L}$ in $1 \mathrm{M} \mathrm{HCl}$ at $60^{\circ} \mathrm{C}$, and the highest inhibition of $83.2 \%$ was obtained by using WE solution of $1,000 \mathrm{mg} / \mathrm{L}$. The extracts mainly inhibit corrosion by adsorption mechanism. Tafel polarisation measurements indicate the extracts behave as mixed type inhibitor. Investigation of the antibacterial activity against oil field microorganism showed the extracts can inhibit SRB, IB and TGB with high efficiency under $1,000 \mathrm{mg} / \mathrm{L}$, which makes extracts potential to be used as bifunctional oil field chemicals.

\section{Competing interests}

The authors declare that they have no competing interests.

\section{Authors' contributions}

GC has conceived the study, formulated the research idea and prepared the manuscript draft version, MZ, RZ, ZM carried out the corrosion inhibition experiments, J Zhang carried out the Microbiological monitoring, and J Zhao participated in its design and coordination. All authors have read and approved the final manuscript.

\section{Author details}

${ }^{1}$ College of Chemistry and Chemical Engineering, Xi'an Shiyou University, Xi'an Shaanxi 710065, People's Republic of China. ${ }^{2}$ Shannxi Hai'an Industry Co., LTD, Xi'an 710065, People's Republic of China.

Received: 25 February 2013 Accepted: 25 March 2013

Published: 7 May 2013

\section{References}

1. Borchardt JK, Yen TF: Oil-field chemistry — enhanced recovery and production stimulation. Toronto: Ontario, Canada; 1988:608-610.

2. Liu YR, Gao ZM, Zhang Z, Shi DF: Electrochemically aided deposition of $\mathrm{TiO}_{2}$ films on Ni-P pre-plated A3 carbon steel. Corrosion Sci Prot Technol 2007, 19:323-325.

3. Jiang JH, Li L, Hu JX, Jiang JQ, Ma AB: New Zinc-phosphating process with $\mathrm{RE}$ catalyzer at low temperature for painting pretreatment of cold-rolling A3 steel sheet. Surf Technol 2007, 36(4):79-81.

4. Sastri VS: Corrosion inhibitors principle and application. New York: John Willey \& Sons; 1998:198-202.

5. Raman A, Labine P, Quraishi MA: Reviews on corrosion inhibitor science and technology. Houstan: NACE International; 2004. 3.
6. Cizek A: Acidizing inhibitors. Mater Perform 1994, 33:56-61.

7. Cruz J, Martinez R, Genesca J, Ochoa EG: Experimental and theoretical study of 1-(2-ethylamino)-2-methylimidazoline as an inhibitor of carbon steel corrosion in acid media. J Electroanal Chem 2004, 566:111-121.

8. Huang YX, Cai J, Zhou JM: Corrosion inhibition of magnolia leaf extracts in acid medium for A3 steel. Applied Chem Indust 2010, 39:538-540.

9. Pan MZ, Cai J, Yu M: Corrosion inhibition of Gum leaves extracts in acid medium for A3 steel. Chem Eng 2012, 2:70-72.

10. Zhao SR, Xu GD, Liao XQ: Preliminary study on the extracts of pine apple waste as corrosion inhibitor and their inhibiting properties to $\mathrm{A} 3$ steel in $\mathrm{H}_{2} \mathrm{SO}_{4}$ solution. Chem Clean 1996, 12(2):4-6.

11. Tang YP, Lou FC, Wang JH, Li YF, Zhuang SF: Coumaroyl flavonol glycosides from the leaves of Ginkgo biloba. Phytochemistry 2001, 58:1251-1256.

12. van Dijk C, Driessen AJ: The uncoupling efficiency and affinity of flavonoids for vesicles. Biochem Pharmacol 2000, 60:1593-1600.

13. Varga E: The protective effect of EGb 761 in isolated isochemical/ reperfused rat hearts. Acta Pharmaceutica Hungarica 2002, 72:265-271.

14. Stanislav J, Shahid M, Koji N: Isolation of ginkgolides A, B, C, J and bilobalide from G. biloba extracts. Phytochemistry 2004, 65:2897-2902.

15. Issaadi S, Douadi T, Zouaoui A, Chafa S, Khan MA, Bouet G: Novel thiophene symmetrical Schiff base compounds as corrosion inhibitor for mild steel in acidic media. Corros Sci 2011, 53:1484-1488.

16. Hegazy MA: A novel Schiff base-based cationic Gemini surfactants: synthesis and effect on corrosion inhibition of carbon steel in hydrochloric acid solution. Corros Sci 2009, 51:2168-2610.

17. Chauhan LR, Gunasekaran G: Corrosion inhibition of mild steel by plant extract in dilute $\mathrm{HCl}$ medium. Corros Sci 2007, 49:1143-1161.

18. Bayol E, Kayakirilmaz K, Erbil M: The inhibitive effect of hexa- methylenetetramine on the acid corrosion of steel. Mater Chem Phys 2007, 104:74-79.

19. da Silva $A B, D^{\prime} E l i a$ E, Da Cunha JA: Ponciano Gomes, carbon steel corrosion inhibition in hydrochloric acid solution using a reduced Schiff base of ethylenediamine. Corros Sci 2010, 52:788-793.

20. Foad El Sherbini EE: Effect of some ethoxylated fatty acids on the corrosion behaviour of mild steel in sulphuric acid solution. Mater Chem Phys 1999, 60:286-290.

21. Abd El Rehim SS, Ibrahim MAM, Khaled KF: Corrosion inhibition and adsorption behavior of 4-aminoantipyrine on carbon steel in $\mathrm{H}_{2} \mathrm{SO}_{4}$. Corrosion Prevent Control 1999, 46(6):157-165.

22. Singh AK, Quraishi MA: Investigation of adsorption of isoniazid derivatives at mild steel/hydrochloric acid interface: electrochemical and weight loss methods. Mater Chem Phys 2012, 123:666-677.

23. Quraishi MA, Ahamad I, Singh AK, Shukla SK, Lal B, Singh V: $\mathrm{N}$-(piperidinomethyl)-3-[(pyridylidene)amino]isatin: a new and effective acid corrosion inhibitor for mild steel. Mater Chem Phys 2008, 112:1035-1039.

24. Ahamad I, Prasad R, Quraishi MA: Adsorption and inhibitive properties of some new mannich bases of isatin derivatives on corrosion of mild steel in acidic media. Corros Sci 2010, 52:1472-1481.

25. Hong J, Kong ZP, Yan L: Aminic nitrogen-bearing polydentate Schiff base compounds as corrosion inhibitors for iron in acidic media: a quantum chemical calculation. Corros Sci 2008, 50:865-871.

26. Li SL, Wang YG, Chen SH, Yu R, Lei SB, Ma HY, Liu DX: Some aspects of quantum chemical calculations for the study of Schiff base corrosion inhibitors on copper in $\mathrm{NaCl}$ solutions. Corros $\mathrm{SCl}$ 1999, 41:1769-1782.

27. Tian Y, Zou B, Li CM, Yang J, Xu SF, Hagerman AE: High molecular weight persimmon tannin is a potent antioxidant both ex vivo and in vivo. Food Res Int 2012, 45:26-30

28. Rice-Evans CA, Miller NJ, Paganga G: Structure-antioxidant activity relationships of flavonoids and phenolic acids. Free Radic Biol Med 1996, 20:933-956.

29. Khaled KF, Hackenman N: Ortho-substituted anilines to inhibit copper corrosion in aerated $0.5 \mathrm{M}$ hydrochloric acid. Electrochim Acta 2004, 49:485-495.

30. Carlson V, Bennett EO, Rowe JA: Microbial flora in a number of oilfield water-injection system. SPE 1961. 1553-G.

31. Kajiyama F, Okamura K: Evaluating cathodic protection reliability on steel pipe in microbially active soils. Corrosion 1999, 55(1):74-80. 
32. Rupi P: Assessment and control of mic in the oil industry in the 20th century. Corrosion 2000:00390.

33. Liu HT, Huang L, Li T, Gu YL: Application and progress in bactericide of sulfate reducing bacteria. J Chinese Soc Corrosion Prot 2009, 29(2):154-160.

34. Chen G, Su HJ, Zhang M, Huo F, Zhang J, Hao XJ, Zhao JR: New bactericide derived from isatin for treating oilfield reinjection water. Chem Central J 2012, 6:91.

35. Riedl KM, Hagerman AE: Tannin-protein complexes as radical scavengers and radical sinks. J Agric Food Chem 2001, 49:4917-4923.3.

doi:10.1186/1752-153X-7-83

Cite this article as: Chen et al:: Investigation of ginkgo biloba leave extracts as corrosion and Oil field microorganism inhibitors. Chemistry Central Journal 2013 7:83.

\section{Publish with ChemistryCentral and every scientist can read your work free of charge}

"Open access provides opportunities to our colleagues in other parts of the globe, by allowing anyone to view the content free of charge."

W. Jeffery Hurst, The Hershey Company.

- available free of charge to the entire scientific community

- peer reviewed and published immediately upon acceptance

- cited in PubMed and archived on PubMed Central

- yours - you keep the copyright

Submit your manuscript here:

Submit your manuscript here:
http://www.chemistrycentral.com/manuscript/ 